\title{
アルミニウムに對するマグネシウムの 固態溶解能に關する研究
}

(嚾和十年一月九日受領昭和十作三月甘五日印刷)

岸野佐吉

\section{(1) 緒言}

著者は鄉に $\mathrm{Al}$ に對する $\mathrm{Mg}_{2} \mathrm{Si}$ の固態溶解能を決定し之を報告した. ${ }^{1>}$

之と全く同柡の方法を以て $\mathrm{Mg}$ の Al 亿對する圆態溶解能に就て研究した.

$\mathrm{Mg}-\mathrm{Al}$ 菜合金の研究は從柬多くの學者によりてなされたのであるが，其中主なるるのにつを其要 點を舉げると次の荄である。

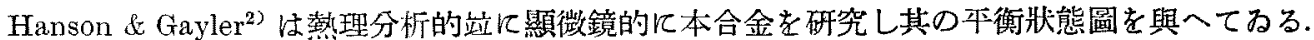

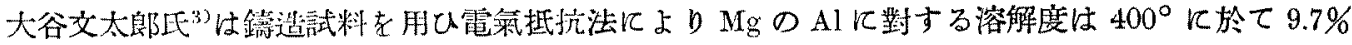
$\mathrm{Mg}, 320^{\circ}$ 亿於て $7.3 \% \mathrm{Mg}$ であると發表してるる.

头に Dix, Keller"雨氏注頗る純度の高い Al を使用し熱理分析法垟に鏡查法により之を研究し, 其 溶解度は第一表の樣であると報告して居る。

\begin{tabular}{lcccccr} 
& \multicolumn{1}{c}{ 第 } & - & 表 & \\
溫喥 $\left({ }^{\circ} \mathrm{C}\right)$ & 451 & 400 & 350 & 300 & 250 & 200 \\
$\operatorname{Mg}(\%)$ & 14.9 & 11.5 & 8.7 & 6.4 & 4.9 & 4.0
\end{tabular}

本研究に於ては軎ら仲延した線を試料として，電氣抵抗法と顯微鏡的試驗とにより之を決定せん とした.

\section{（2）電氣抵坑法に依る燒入試料の時效變化測定}

著者の實験方法は試料を高溫から連續的に水中に燒入した後，平衡状態となるを待つて其電氣抵 抗を测造主るのである，從つて本合金が燒入徭電氣抵㧤の變化有りや否や，又有りとすれ何時間 で完了するか老最初化研究する必要がある。

著者の使用した材料中 Al は British Aluminium Co. 製の塊狀で不純物として Si 0.17\% Fe 0.13\%

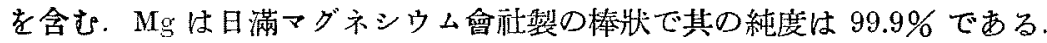

先づ電氣嘘にて計算量の Al 老熔融し，次に計算量の $\mathrm{Mg}$ 老點火せね梯手早く $\mathrm{Al}$ 融液中に押込み， 全く揢け込んだ後 $25 \mathrm{~mm}$ 角，長さ $250 \mathrm{~mm}$ の銡物とした. 斯くして得た試料の成分は第二表の樣 である。

\begin{tabular}{|c|c|c|c|}
\hline & 第 & 表 & \\
\hline 試料番號 & $\operatorname{Mg}(\%)$ & $\mathrm{Si}(\%)$ & $\mathrm{Fe}(\%)$ \\
\hline B 3 & 3.30 & 0.12 & 0.30 \\
\hline B 5 & 5.31 & 0.13 & 0.27 \\
\hline B 8 & 8.00 & 0.12 & 0.30 \\
\hline
\end{tabular}

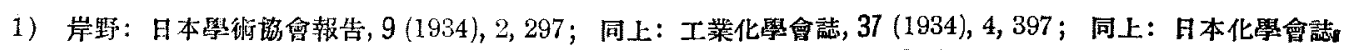
55 (1934), 6, 528, 533 . 2) D. Hauson \& M. L. V. Gayler: J. Inst. M., 24 (1920), 201.

3) B. Otani: $J$. Chem. Ind. (Japan), 25 (1922), 36 4) Dix, E. H. Jr. \& F. Keller: Proc. Inst. M., A. I. M. E (1929), 351 
次に此等の鑄物を常法により直徑 $7 \mathrm{~mm}$ 迄熱間旺延し, $2 \mathrm{~mm}$ 迄棆間延伸を行つた. 但し試料 B 8 は熱間厴延不能にて試料を作り”得なかつた. 茲に於て試料 B 3 及 B 5 を取り既远のつ裝置及方法に より此等の試料を $520^{\circ}$ の熔融硝石浴中にて一時間燒鈍し之を水中に燒入して, 直に恒溫油槽中に收 め，其電茶抵抗の變化を精密に測定した．此等の結果は第 1 圖の樣である.

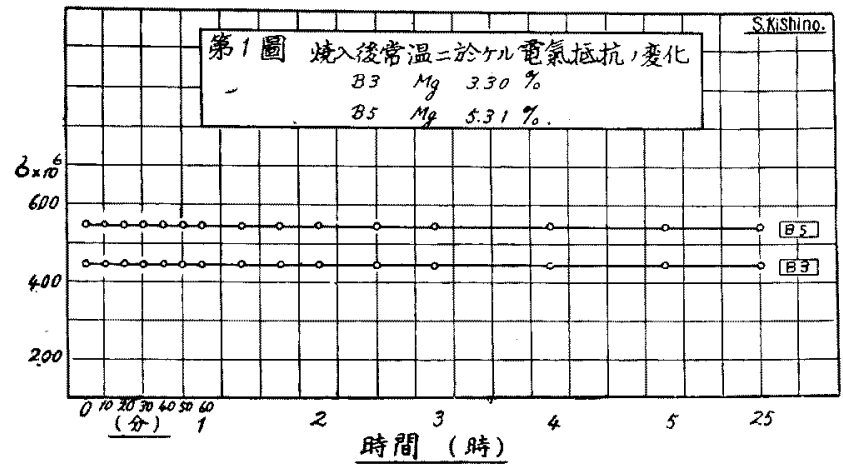

之れによれば $\mathrm{Mg}-\mathrm{Al}$ 合金はジュラルミン型及アルドライ型合金と異り，燒入後常溫に於て電氣抵 抗の變化のないてとを知る。

\section{（3）燒入溫度の相違に伴ふ電氣抵抗の變化}

前實驗に於て本合金は憢入後常溫に於ては電氣抵抗の變化のない事を確めたが故に，著者は本研 究に於ては燒入後長時間常溫に放置する事なく直に電氣抵抗を測定する事とした. 扱て前述のB 3 及 B 5 なる試料を $520^{\circ}$ の熔融硝石浴中に入れ 50 時間燒鈍して水中に燒入れし均一なる固溶體粗織 となして，次に各試料老約 $1500 \mathrm{~mm}$ 几切斷し夫及追番號を附した，今之等の試料を各種の溫度にて 1 時間乃至 5 時間加熱したる後第 2 圖，第 3 圖立泣第 4 圖に示す㥞な冷却速度を以て冷却しつつ，

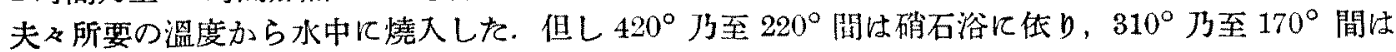
空氣浴により，240 乃至 $60^{\circ}$ 間は油浴に位りて夫々熱處理を施したのである.

汃くて得たる各種の試料について其の電氣抵抗を精 密に測 定した. 其の結果は第 5 圆, 第 6 圆立 に第 7 圖の様である.

之れに依れば燒入溫度一電氣抵抗曲線に於て顯著なる轉向點がない. 郎ち Mg $3.3 \%$ 合有する合 金も5.3\% を含有する合金当共に $420^{\circ}$ から $60^{\circ}$ 迄の間に於て組織の變化がない事を知る. 之れ温店 が低く冾却速度が速いために充分固塎體から析出晶が出で得ないためか，又は常溫に於て $5 \%$ 程度 の $\mathrm{Mg}$ は固溶するれめであらう。

叉是等の試料につき顯徽鏡試驗を行つたが特に組織の變化をば認め得なかつた。

\section{(4) 結 語}

$\mathrm{Mg}-\mathrm{Al}$ 系合金の Al 側に於ける Mg の固態溶解能を電氣抵抗法端に鏡杏法に住り研究した。

(1) 本合金は燒入後常溫に於て時效變化のない事を電氣抵抗法に任つて决定した。

(2) 燒大溫度一電菊抵抗曲線に轉向點が現はれない。

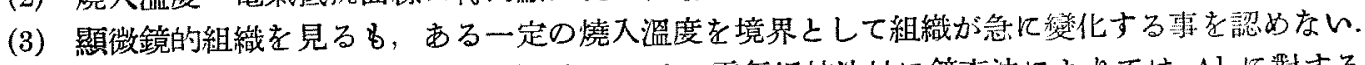
之を要するに Mgの含有分 $5 \%$ 以下にあつては, 電氣抵抗法立に鏡查法によりては Al に對する Mgの固態溶解能を決定する事は困難である.

5）岸野：日本學術協會報告，前出. 

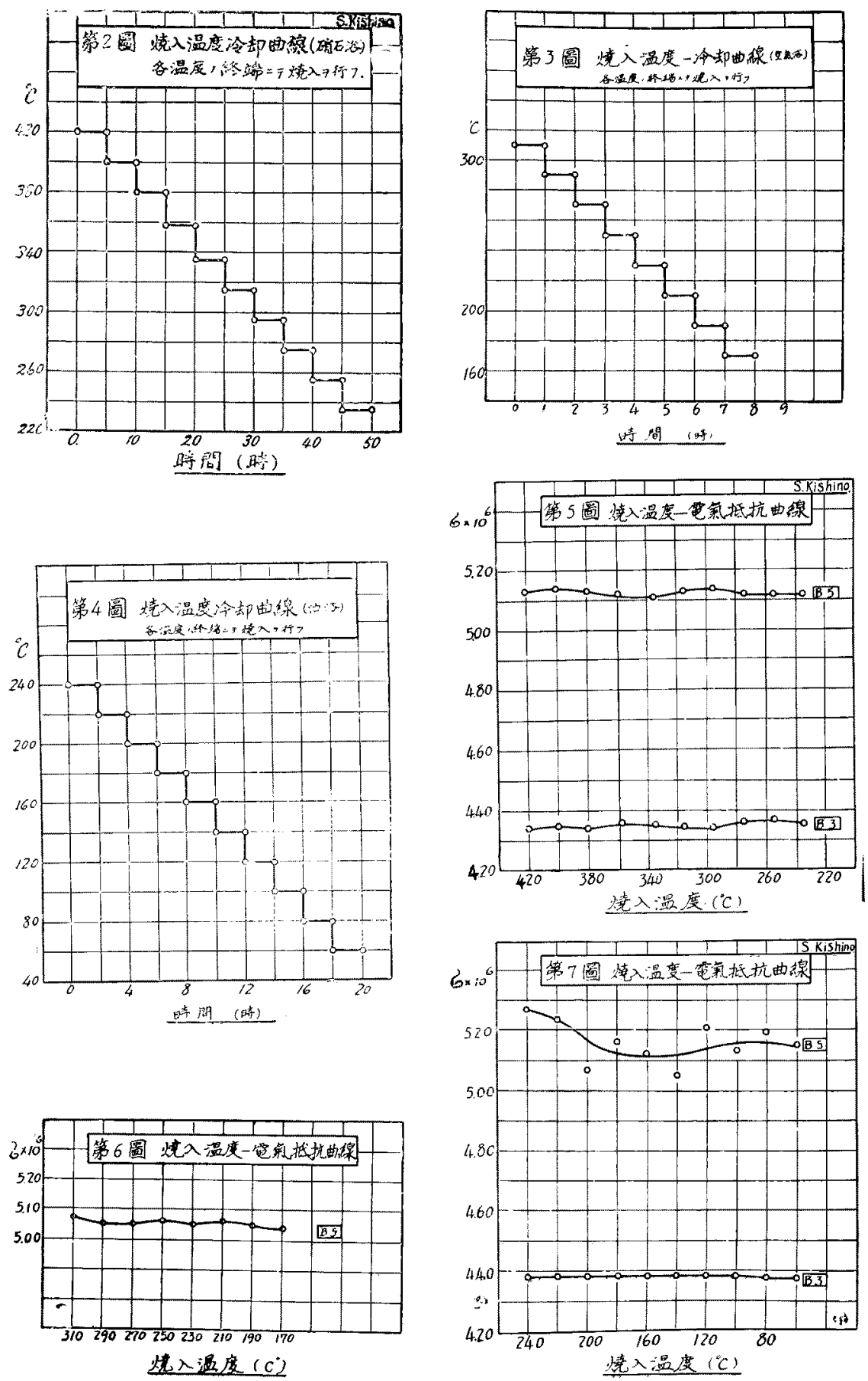

終りに臨み有谷なる助言を賜はりをる京都帝國大學宇野教授に深甚の謝意を表す。 